\title{
NEGATIVE PRONOUNS IN SLOVENE: A MINIMALIST ACCOUNT
}

\section{Introduction}

In this paper we examine Slovene negative pronouns from a cross-linguistic perspective and propose an account of their observed properties in terms of minimalist feature checking theory as developed by Chomsky $(1995,1998,1999,2001)$ and modified by Pesetsky \& Torrego $(2000,2002)$ and Hiraiwa (2000).

Based on the standard typology of items associated with negation (negative quantifiers, negative polarity items, n-words), we argue that Slovene negative pronouns are n-words. They form a special subcategory of negative quantifiers marked with an uninterpretable negative feature. The uninterpretable negative feature requires that it be checked and deleted in overt syntax. This is accomplished by the operation Agree, with the uninterpretable negative feature being checked against the interpretable negative feature of an overt negator in the Negative Phrase and deleted. Once their uninterpretable feature is deleted, n-words are free to undergo any further syntactic operations required in the course of the derivation.

The paper is organized as follows. Section 1 is a brief outline of the theoretical framework which forms the background to this paper. Section 2 deals with n-words in Slavic; in 2.1 we sketch out previous generative analyses of $n$-words in Serbian/Croatian, Polish and Russian, and then focus on Slovene n-words, examining their basic descriptive properties and comparing them with those in the afore-mentioned Slavic languages, negative polarity items and negative quantifiers in English, and n-words in Romance (2.2). In section 3 we develop a minimalist analysis of nwords in Slovene which captures all the relevant properties of Slovene n-words in constructions with the overt negator (3.1) and in constructions where the overt negator is absent (3.2). Section 4 concludes the paper.

\section{Theoretical background}

\subsection{Basic concepts and assumptions}

Our account of Slovene n-words follows the basic tenets of the Minimalist Program (Chomsky 1995 and subsequent work) and builds on its core idea that syntactic operations are triggered by feature checking requirements.

A lexical item is defined as a set of phonological, semantic, and formal features. Formal features occur both in lexical and functional categories. Features are of two types: interpretable $(i \mathrm{~F})$ or uninterpretable $(u \mathrm{~F})$. Pesetsky and Torrego (2002: 2) argue that the (formal) features of a lexical item $\mathrm{L}$ may belong to either category:

"(A) features which have a semantic value on $L$ (interpretable features of $L$ ), 
(B) features that have a semantic value on some other lexical item L', but have no value on $L$ (uninterpretable instances of interpretable features)[.]" 1 Since uninterpretable formal features are relevant only to the computational system and play no role at the interface levels of Phonetic Form (PF) and Logical Form (LF), they must be eliminated in the course of the derivation, i.e. in overt syntax. The syntactic operation that eliminates uninterpretable features is called Agree (Chomsky 1999: 3). Agree is a relation between a probe and a goal, the former having an $u \mathrm{~F}$ and the latter a matching $i$. For example, an element with the uninterpretable [neg] feature (the probe) enters Agree with an element containing the interpretable [neg] feature (the goal) (1a). For Agree to be triggered, the matching probe and goal must be active. They are active only if they meet the following criteria: (i) the goal must be in the c-commanding domain of the probe, (ii) the probe must have an unchecked $u \mathrm{~F}$, (iii) the goal must have either an $i \mathrm{~F}$ (1a) or $u \mathrm{~F}$ that has previously entered Agree with another $i \mathrm{~F}(1 \mathrm{~b})^{2}$

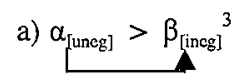

b) $\alpha_{\text {[uneg] }}>\beta_{\text {[uneg] }}>\gamma_{[\text {[ineg] }}$

According to the X-bar theory of phrase structure the basic clause structure is as shown in (2a). A clause is a maximal projection IP headed by the functional category I. The specifier of IP is the subject of IP and the VP is the complement of I. The type of clause (i.e. declarative, interrogative, imperative) is determined by the functional category C(omplementizer), which takes IP as its complement, so that a full clause has the structure $(2 \mathrm{~b})$.
a) [IP Spec [r I VP]]
b) $\left[{ }_{C P} \operatorname{Spec}\left[{ }_{C}, C\left[{ }_{I P} \operatorname{Spec}[\mathrm{r} \text { I VP }]\right]\right]\right]^{4}$

More recently, however, Chomsky $(1998,1999,2001)$ has proposed to eliminate the $\mathrm{X}$-bar theory as a separate module of the grammar, arguing that restrictions on the form of structural descriptions follow directly from the properties of structurebuilding processes themselves. Chomsky (1998: 15) proposes the following system of core functional categories: (i) C(omplementizer) expressing force/mood, (ii) $\mathrm{T}$ (ense) expressing tense/event structure, and (iii) $\mathrm{v}$ (light verb) heading transitive construc-

\footnotetext{
${ }^{1}$ The authors (ibid.) also discuss a third possibility: “(C) features with no semantic value on any lexical item, including L (purely uninterpretable features of L)", but show that this subclass of features is non-existent.

2 The last criterion, suggested and argued for by Pesetsky and Torrego (2000: 23), is a slight departure from Chomsky's original proposal (1999: 3) that "[...] a relationship Agree hold[s] between $\alpha$ and $\beta$, where $\alpha$ has interpretable [...] features and $\beta$ has [...] uninterpretable ones, which delete under Agree."

$3>$ marks c-command.

${ }^{4} \mathrm{CP}=$ Complementizer Phrase; IP = Inflectional Phrase; VP = Verb Phrase, Spec = specifier.
} 
tions. The hierarchical ordering of these elements depends on their selectional properties: $\mathrm{C}$ selects $\mathrm{T}$ while $\mathrm{T}$ and $\mathrm{v}$ select verbal elements (2c). Each core functional projection also allows for a specifier position (2d):
c) $\left[c\left[\left[_{T}[v[v]]\right]\right]\right.$

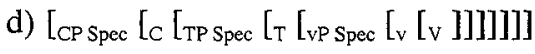

It is noteworthy that Chomsky (op. cit.: 15, fn 31) uses functional categories C and T "as surrogates for richer systems", such as those proposed by Rizzi (1997) and Cinque (1999). For the purpose of our analysis, we therefore expand the proposed hierarchy in (2d) by adding the functional category of Neg(ation), which we take to be selected by $\mathrm{T}: 5$

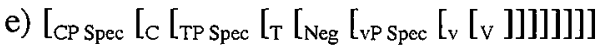

\section{2 Negative quantifiers, negative polarity items and n-words}

Negative quantifiers (NQs), negative polarity items (NPIs) and n-words are categories commonly associated with the category of negation. NQs are those lexical elements which are inherently marked for negation; they independently express negation, and cannot be used without the negative meaning:

(3) a) Nobody does (*not) it or has (*not) done it.

Standard English

b) We have nothing to report.

In contrast to NQs, NPIs are not inherently marked for negation, their negative meaning depends on the presence of an overt marker of negation, which may be either the negator (4a) or a NQ (4b). It is generally assumed that NPIs are indefinite pronouns which must be properly licensed by special polarity contexts. In particular, they must be in the c-commanding domain of an element forming polarity contexts. These include syntactic structures such as negatives (4a,b), interrogatives (4c) and superlatives (4d). Without an accessible licenser, NPIs are acceptable only if used as assertives (4e).

(4) a) George has *(not) seen anything / anybody.

b) Nobody has said anything.

c) Has anybody arrived yet?

d) This is the dumbest idea I have ever heard.

e) He's hungry. He'll eat just anything.

${ }^{5}$ The proposed hierarachical order only suggests that Negation is selected by Tense, which is supported by the fact that in negative structures negation does not have scope over the tense operator, but does not in any way determine the exact position of Neg within an articulated T- system. 
Zanuttini (1991) and Haegeman (1995) put forward three diagnostic tests for differentiating NQs from NPIs. According to these authors, only NQs but not NPIs function as overt markers of negation (5a), can be modified by almost-like adverbs (5b) and can be used as independent answers to wh-questions (5c):

NQs

a) I have nothing to say.

b) I know almost nobody here.

c) Who do you recognize here? Nobody.
NPIs

*I have anything to say.

I don’t know (*almost) anybody here.

Who do you recognize here? *Anybody.

The term 'n-words' was first introduced by Laka (1990). It denotes a set of lexical items which enter the negative concord (NC) relation with the negator and seem to share the morpho-syntactic properties of both NQs and NPIs. Analysing n-words in Italian, a standardly assumed NC language, Acquaviva (1999: 138-139) distinguishes canonical and non-canonical licensing contexts for n-words. In canonical licensing contexts, i.e. negative contexts, the (Italian) n-words display properties of NQs as well as NPIs: they function as the overt markers of negation in the preverbal position $(6 a, b)$, but require the presence of an overt marker of negation in order to be properly licensed in the postverbal position (6c). In non-canonical licensing contexts, i.e. non-negative contexts, n-words are devoid of negative meaning (6d,e), and exhibit the same syntactic patterns as English NPIs (cf. (4)).

(6) a) Nessuno / nessun uomo è infallibile.

'Nobody /no man is infallible.'

Acquaviva (1999), 138: (1a)

b) NESSUNO ho invitato. 'NOBODY I invited.'

Acquaviva (1999), 138: (1b)

c) Non ho invitato nessuno.

Acquaviva (1999), 138: (1c)

'I did not invite anybody.'

d) È venuto nessuno?

Acquaviva (1999), 139: (2)

'Has anyone come?'

e) È l'idea più stupida che abbia mai sentito.

'It's the dumbest idea I have ever heard.'

Acquaviva (1999), 139: (5a) 


\section{$2 \mathrm{~N}$-words in Slavic}

\subsection{Previous accounts}

To the best of our knowledge, the present paper is the first attempt at describing Slovene n-words within the generative framework. As a starting point, we therefore give a brief overview of the generative analyses of $n$-words from languages that are historically and/or typologically closely connected with Slovene. In particular, we focus on Serbian/Croatian, Polish and Russian, ${ }^{6}$ which have all been recognised as typical NC languages, displaying both phenomena associated with NC: negative spread and negative doubling. ${ }^{7}$

Progovac (1994) investigates the nature of Serbian/Croatian n-words and NPIs from a cross-linguistic perspective and concludes that they are subject to the binding conditions. She states that the distribution of n-words in Serbian/Croatian is straightforward since "they can only occur in a clause which contains an overt negative particle ne no matter whether they are in the object, subject, or adjunct position[.]" (op. cit.: 40). According to her analysis, Serbian/Croatian, Russian n-words and strict NPIs in English are subject to Principle A of the Binding Theory requiring that "[a]ll NPIs must be bound." Progovac (op. cit.: 90-94) The subject/object asymmetry which can be observed with an English NPIs (8b,b') but not with Serbian/Croatian n-words $\left(8 \mathrm{a}, \mathrm{a}^{\prime}\right)$ is dealt with in terms of different placement of clausemate negation: in Serbian/Croatian the negation originates in the NegP below the IP, and then moves to IP, whereas in English the negation remains in situ Progovac (1994: 35).
(8)
a) Milan *(ne) vidi ništa.
Progovac (1994), 40: (107)
Milan not see nothing
'Milan cannot see anything.

a) Nitko *(ne) vidi Milana.

Nobody not see Milan-ACC

Progovac (1994), 40: (108)

'Nobody can see Milan.'

b) Mary does not see anybody.

b') *Anybody does not see Mary.

\footnotetext{
${ }^{6}$ For details see, among others, Progovac (1994) for Serbian/Croatian, Przepiórkowski and Kupść (1997a,b) for Polish, and Brown (1999) for Russian.

${ }^{7}$ Negative concord is a cover term for all multiple occurrences of negative elements within a syntactic structure which yield a single semantic negation. Van der Wouden (1997: 182) distinguishes two forms of negative concord: (i) negative spread and (ii) negative doubling. In the case of the latter "a distinguished negative element shows up in all sentences that contain a negative expression", whereas in the case of the former the negative meaning is distributed over any number of indefinite expressions within the scope of the negative expression.

(i) negative spread: Nobody said nothing to nobody. Colloquial English van der Wouden (1997), 182: (6a)

(ii) negative doubling: Je $n$ 'ai vu personne.

Standard French van der Wouden (1997), 183: (7a)

I not-have seen nobody

'I haven't seen anybody.'
} 
Przepiórkowski and Kupść (1997b: 130-1) argue that "licensing conditions on Polish n-words differ from those on English Negative Polarity Items [...] or Italian nwords." First, their meaning does not depend on the pre-/post- verbal status of nwords $(9 \mathrm{a}, \mathrm{b})$, and second, none of the NPI-licensing contexts other than negation can license Polish n-words (9b,c). Przepiórkowski and Kupść (1997a: 13) conclude that "the only common features of these words are their quantifier-like character and the 'negation' triggering properties[.]"

(9) a) Nikt *(nie) przyszedl. Przepiórkowski and Kupść (1997b), 130: (2a) Nobody not came

Nobody came.'

b) Marysia *(nie) dała nikomu ksiąžki. Przepiórkowski and Kupść (1997b), 130: (2c) M. not gave nobody book

'Mary didn't give anybody a/the book.'

c) ${ }^{*}$ Czy nikt dzwonił? Przepiórkowski and Kupść (1997b), 131: (5) Q nobody phoned

'Has anybody phoned?'

d) *Wątpię žeby nikt dozwonił. Przepiórkowski and Kupść(1997b), 131: (7) doubt-I that nobody phoned 'I doubt if anybody phoned.'

Russian n-words show a very similar pattern to that of n-words in Serbian/Croatian and Polish. They can be used with negative meaning only, requiring the presence of the negator (with the exception of elliptical constructions such as (10c)). They are not licensed in non-negative contexts (10e), and can be modified by adverbs such as almost (10d):

(10) a) Ja *(ne) videl nikogo.

I NEG saw no-who

Brown (1999), 24: (14)

'I saw no one.'

b) Ja nikomu ničego ne davala. Brown (1999), 31: (29)

I no-who no-what NEG gave

'I didn't give anything to anybody.'

c) Kogo ti videl? Nikogo.

who you saw nobody

Brown (1999), 24: (13)

'Who did you see?' 'Nobody.' 
d) On počti ničego *(ne) delal. Brown (1999), 24: (16b) he almost no-what NEG did 'He did almost nothing.'

e) *Nitko zvonil? Brown (1999), 21: (6b) no one called 'Has anyone called?'

Brown (1999) claims that NC in Russian is a consequence of a feature checking mechanism as developed in Chomsky (1995). She argues that Russian n-words are marked with an uninterpretable [uneg] feature which must be checked by the [ineg] feature in the NegP. The [uneg] feature can be checked in two ways: "[e]ither the entire negative constituent raises to check this feature or, in structures where the negative constituent occupies a postverbal position and presumably does not ocuppy [Spec, NegP] in the overt syntax, the abstract feature [NEG] covertly raises to adjoin to the head of NegP." (Brown, op. cit.: 33). The established mechanism checks and erases the [ $u$ neg] features of $n$-words, but at the same time leaves the [ineg] feature of NegP intact, which "[...] is interpreted as negative closure of events, i.e., sentential negation, and the negative pronouns are interpreted as indefinites in the domain of existential closure[.]" (Brown, ibid.) ${ }^{8}$

\subsection{Slovene n-words}

Slovene is a NC language, displaying both the negative doubling and the negative spread: Slovene n-words typically enter the $\mathrm{NC}$ relation ${ }^{9}$ with the negator (negative doubling (11a)), and with each other (negative spread (11b)). The presence of the negator $n e$ is obligatory in both cases (cf. Polish (9a,b) and Russian (10a,b)). As shown in (11 a', $\left.\mathrm{b}^{\prime}\right)$, there is no subject/object asymmetry (cf. English NPIs - (8b, b')).
a) Nihče *(ne) bo odšel. nobody not will leave 'Nobody will leave'
a') Janez ne pozna nikogar. Janez not knows nobody-gen 'Janez doesn't know anybody.'

\footnotetext{
${ }^{8}$ Even though Brown's account suggests that Russian n-words should be treated as (a special subcategory of) NQs rather than NPIs, her argumentation explicitly bypasses the question of whether Russian n-words are NQs or NPIs. However, it is questionable whether we can discuss the derivation of NC reading with structures containing $n$-words, before determining their (non)-negative status. For example, if n-words are nonnegative to start with, then there is no need to explain the derivation of $\mathrm{NC}$, since such constructions have only one negative element, i.e. the negator.

${ }^{9}$ In some cases, n-words may enter the double negation relation (DN), especially when under strong stress (i). However, it must be noted that for most speakers this interpretation is always secondary:

(i) NIHČE ni rekel ničesar.

NOBODY not+was said anything

'Nobody said anything.' (NC)

'Nobody said nothing.' (DN)
} 
b) Nihče ${ }^{*}($ ne) bo rekel ničesar. nobody not will say nothing 'Nobody will say and anything.' b') Nihče ne pozna Janeza. nobody not knows Janez-gen 'Nobody knows Janez.'

With the exception of negation, any other contexts that license NPIs in English and $\mathrm{n}$-words in Romance languages such as Italian or Spanish fail to license Slovene nwords. Thus they cannot be used in questions (11c), superlatives (11d) and adversative predicates (11e) without negative meaning (cf. Polish $(9 \mathrm{c}, \mathrm{d})$ and Russian $(10 \mathrm{e})$ ):

(11) c) *Ali je nihče prišel?

$\mathrm{Q}$ is nobody arrived

'Has anybody arrived.'

d) *To je najbolj neumna domislica, ki sem jo nikoli slišal. this is most dumb idea that is it-acc never heard 'This is the dumbest idea I have ever heard.'

e) ${ }^{*}$ Dvomim, da je nihče poklical. doubt that nobody called 'I doubt that anybody called.'

Like English NQs, Slovene n-words can be modified by almost-like adverbs (cf. Russian (10d)):

(11) f) Janez ni poznal skoraj nikogar na zabavi.

J. not+is known almost nobody on party

'John knew almost nobody at the party.'

Slovene n-words can be found without an overtly expressed negator in short answers to wh-questions (11g), co-ordinated structures $(11 \mathrm{~h})$, as comparison phrases (11i), and contextually dependent statements expressing contrast (11j):

(11) g) Koga si videl? Nikogar.

Who is seen Nobody-gen

'Who did you see? Nobody.'

h) Janez je videl Marijo in nikogar drugega.

J. is seen M.-acc and nobody-gen else

'John saw Mary and nobody else.'

i) Janez je visok kot nihče drug.

$\mathrm{J}$. is tall as nobody else

'John is as tall as nobody else.' 
j) Poznaš koga na ministrstvu? Poznam nikogar, *(lahko pa vprašam). know anybody on Ministry Know nobody, can but ask 'Do you know anybody from the Ministry? I don't, but I can ask.'

To sum up, Slovene n-words have several characteristics in common with n-words in Serbian/Croatian, Polish and Russian: (i) they are like NQs in that they can be used with negative meaning only, can function as independent answers to wh-questions and can be premodified by almost-like adverbs; (ii) they resemble NPIs in that they require the presence of the negator (with the exception of elliptical constructions); however, they cannot occur in non-negative polarity contexts licensing NPIs in English and n-words in Romance languages such as Italian and Spanish; (iii) they are not sensitive to syntactic position (pre-/post-verbal), unlike Romance n-words, whose negative (i.e. NQ) and non-negative (i.e. NPI) status depends on their syntactic position.

The table below summarizes the properties of NQs, NPIs and n-words in the languages discussed.

\begin{tabular}{|c|c|c|c|c|}
\hline & $\begin{array}{c}\text { inherent } \\
\text { neg. meaning }\end{array}$ & $\begin{array}{c}\text { short answers to } \\
\text { wh-questions }\end{array}$ & $\begin{array}{c}\text { modified by } \\
\text { adverbs }\end{array}$ & $\begin{array}{c}\text { presence of } \\
\text { negator }\end{array}$ \\
\hline English NQs & $\checkmark$ & $\checkmark$ & $\checkmark$ & $x$ \\
\hline English NPIs & $x$ & $\mathbf{x}$ & $x$ & $\checkmark$ \\
\hline $\begin{array}{l}\text { Slovene/Russian/Polish/ } \\
\text { Serbian/Croatian n-words }\end{array}$ & $\checkmark$ & $\checkmark$ & $\checkmark$ & $\checkmark$ \\
\hline Romance n-words & $\begin{array}{l}\checkmark \text { neg-contexts } \\
x \text { otherwise }\end{array}$ & $\begin{array}{l}\checkmark \text { neg. contexts } \\
x \text { otherwise }\end{array}$ & $\begin{array}{l}\checkmark \text { neg. contexts } \\
* \text { otherwise }\end{array}$ & $\begin{array}{l}\checkmark \text { post-verbal in } \\
\text { neg. contexts } \\
\times \text { pre-verbal in } \\
\text { neg. contexts } \\
\text { and otherwise }\end{array}$ \\
\hline
\end{tabular}

Table 1: Distribution of NQs, NPIs and n-words.

\section{The proposal}

In this section we develop an analysis of Slovene n-words in terms of minimalist feature checking theory.

Based on the Slovene data discussed in 2.2, we propose the following hypothesis:

(12) Slovene n-words form a special subcategory of NQs and bear an [uneg] feature which is checked against the [ineg] feature of the negator ne and deleted under Agree. Once [uneg] is deleted, n-words can undergo any further syntactic operation if required by the computation.

\subsection{The derivation}

Let us assume that at the intermediate derivational stages (13a', $\left.b^{\prime}\right)$ of sentences $(13 \mathrm{a}, \mathrm{b})$, the relation Agree is established between the [uneg] of n-words and [ineg] of the negator ne. In the case of multiple occurrence of n-words such as (13b), Agree must be established between [ineg] and each and every [uneg].

10 Non-negative polarity contexts. 
(13) a) Janez ne ve ničesar.

J. not knows nothing

'John does not know anything.'

b) Nihče ne ve ničesar. nobody not knows nothing

'Nobody knows anything.'
a') $\left[_{\mathrm{Neg}} \mathrm{ne}_{[\text {[neg] }} \mathrm{ve}[\mathrm{vp}\right.$ Janez [v $]$ [v ničesar $\left.{ }_{[u \mathrm{neg}]}\right]$
b') $\left[_{\text {Neg }} n_{[\text {[ineg] }}\right.$ ve $\left[_{\mathrm{vP}}\right.$ nihče $_{[\text {[uneg] }}[\mathrm{v}]\left[\mathrm{v}\right.$ ničesar $\left.{ }_{[u n e g]}\right]$

But how can Agree be established? Under the minimalist checking theory as developed by Chomsky $(1998,1999,2001)$, two problems arise. First, Agree requires that the c-commanding probe bears an unchecked $u \mathrm{~F}$, and the c-commanded goal an $i \mathrm{~F}$ or $u \mathrm{~F}$ (see section 1.1). In (13a', $\mathrm{b}^{\prime}$ ) the probe ne has an interpretable [neg] feature, which makes it inactive. Second, in (13b') two operations Agree are needed; the first between $n e$ and nihce, and the second between ne and ničesar. The latter step violates The Defective Intervention Constraint (Chomsky 1998: 38) which bans Agree between the probe $\alpha$ and the goal $\gamma$ with and intervening $\beta$ which is inactive due to a prior Agree with some other probe. Hence, even if ne were active, Agree between ne and ničesar in (13b') is ruled out by the intervening element nihče, having previously entered Agree with the negator.

The violation of the Defective Intervention Constraint is no longer at issue, however, if we adopt the theory of Multiple Agree as a special instance of multiple feature checking, proposed by Haraiwa (2000). Analysing various raising phenomena in Japanese, Hiraiwa (op. cit.: 69) argues that in addition to Agree, there is also the operation Multiple Agree which is established between a single probe and all the matching goals "at the same derivational point derivationally simultaneously." To illustrate, the matching goals $\beta$ and $\gamma$ in (13c) enter Multiple Agree with the probe $\alpha$ simultaneously at the same derivational point.

(13) c) $\alpha>\beta>\gamma$

(Agree $(\alpha, \beta, \gamma)$ where $\alpha$ is a probe and both $\beta$ and $\gamma$ are matching goals for $\alpha$.) Hiraiwa (2000); 70: (8)

Implementing the proposed operation, we analyse the multiple feature checking between the negator ne and the n-words nihče and ničesar in (13b) as an instance of Multiple Agree, where Agree is established between the [ineg] of the probe ne and the two unchecked [uneg] of the matched goals nihče and ničesar simultaneously at the derivational point (13b'): 
The next question to address is why the negator ne with the [ineg] feature can function as an active probe at the derivational points $\left(13 a^{\prime}, b^{\prime}\right)$. We suggest that an answer to this question be sought in the nature of NC languages. Several generative accounts of NC languages (Zanuttini (1991), Haegeman (1995), Suñer (1995), Brown (1999), among others) claim that NC should be seen as an instantiation of negative absorption where "one negative operator ranges over a number of variables" (Haegeman 1995: 79). In the spirit of minimalist feature-driven syntax, we take negative absorption to be the result of a feature checking operation. Suppose the negator is subspecified for an [attract all] feature whose requirement is to attract all the elements with the $[\mathrm{neg}]$ feature. This operation allows the negative operator to absorb all the formal negative features of n-words, which results in a single element marked for negation at LF, and consequently also in a single negation interpretation.

To provide an example, (13d) shows the feature checking mechanism Multiple Agree of the syntactic object at the derivational point (13b'), resulting in (13e):

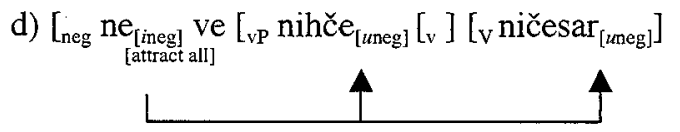

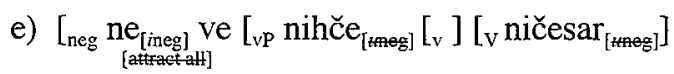

Once the [uneg] features of n-words are checked and deleted, n-words are free to enter any further non-Neg triggered syntactic operations. For example, nihče in (13d) raises to the subject position for Case checking at the derivational point (13f).

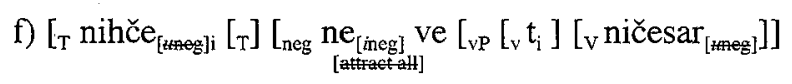

The analysis of Slovene n-words we propose in this section straightforwardly explains why (in non-elliptical constructions) Slovene n-words require the presence of an overtly expressed negator but are at the same time not affected by their relative position (i.e. preceding or following the negator). It also accounts for the subject/object asymmetry displayed by English NPIs but not by Slovene (and Serbian/Croatian) n-words (see sections 2.1, 2.2). Whereas English NPIs require a ccommanding negative element at LF, Slovene as well as Serbian/Croatian n-words require only that their [uneg] be checked. The movement of English NPIs out of the c-commanding domain destroys the c-commanding relation, which results in ungrammaticality (cf. (8a)). The movement of Slovene or Serbian/Croatian n-words out of the c-commanding domain of a negative element once their [uneg] features have been checked (as in (13 f)) does not violate any syntactic principle, and the ensuing structures are well-formed (cf. (13b), also (11a'), (8a, a')). 
Our proposal departs from the minimalist analysis of Russian n-words put forward by Brown (1999), see section 2.1. While she proposes two possible mechanisms of feature checking - overt movement of preverbal n-words to [Spec, NegP] and covert movement of the [neg] feature of postverbal n-words to NegP - our analysis involves only one derivational step: all [neg] features of $n$-words, regardless of their overt pre- or post-verbal position, are checked at the same time at the same derivational point under Agree. In the minimalist framework, where considerations of economy play a crucial role, this is clearly a conceptually desirable result.

\subsection{Elliptical Constructions}

So far we have dealt with only those structures containing n-words in which the negator is overt. We now turn to $n$-words found in sentences without an overt negator, as in $(11 \mathrm{~g}-\mathrm{j})$. For these instances we suggest that they be treated as elliptical constructions since they all meet the criterion of verbatim recoverability requiring that all the elided words whose meaning is implied be recoverable. In (14) the strikethrough marks the elided but recoverable elements of sentences (11g-j):

a) Koga si videl? a') Nikogar Who did seen Nobody-gen 'Who did you see? Nobody.'

\section{mote.}

not+am seen

b) Janez je videl Marijo in nikogar drugega

$\mathrm{J}$. is seen M.-acc and nobody-gen else not+is seen

'John saw Mary and nobody else.'

c) Janez je visok kot nihče drug.

$\mathrm{J}-a c c$ is tall as not tall nobody-nom else

'John is as tall as nobody else.'

d) Poznaš koga na ministrstvu? poznam nikogar, *(lahko pa vprašam). know anybody on Ministry I not know nobody, can but ask 'Do you know anybody from the Ministry? I don't but I can ask.'

There is one additional piece of evidence that supports our claim that the structures (14) are elliptical. In (14a) the n-word is in the genitive case, which typically occurs with a negated verb (the 'Genitive of Negation'). ${ }^{11}$ According to the minimalist checking theory, the case of the NP complement of a transitive verb is checked in the verbal domain. This leads to the conclusions that in (14a') there must be at least a fully developed verbal domain for nikogar in (14a) to check its genitive case.

11 Compare:

(i) Janez ljubi Meto.

Janez loves Meta-acc

'John loves Daisy.'

(ii) Janez ne ljubi Mete.

Janez not loves Meta-gen

'John does not love Daisy.' 
Lasnik (1999: 151-173) argues that only overt syntax can create an ellipsis site and that ellipsis can easily be analysed as a PF deletion phenomenon. He claims that pseudogapping, a subcategory of ellipsis, is a PF deletion of VP with the remnants having moved out of VP. To illustrate, in (15a) the second VP eat the grapes undergoes PF deletion. Prior to this operation, the internal argument the grapes raises in overt syntax out of the VP that is deleted at PF, (15b):

(15) a) Bill ate the peaches and Harry will the grapes. Lasnik (1999); 152: (2b)

b) $\ldots\left[\left[_{\mathrm{TP}}\right.\right.$ Harry $\left[_{\mathrm{T}}\right.$ will $]\left[_{\mathrm{FP}} \text { the grapes }{ }_{\mathrm{i}}\left[_{\mathrm{F}}\right] \mathrm{f}_{\mathrm{HP}} \mathrm{t}_{\mathrm{i}}\right]^{12}$

Kim (2001) further develops Lasnik's proposal and concludes that pseudogapping is syntactic focus movement followed by the PF deletion of VP. Kim (op. cit.: 67-68) defines syntactic focus movement as an operation driven by a formal [focus] feature representing accented new information. In (15b), the [focus] feature on the constituent the grapes is thus checked in overt syntax via the operation Move (5c):

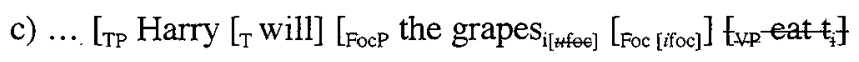

In the light of this proposal we return to Slovene elliptical constructions (14). We suggest that in (14a') nikogar bears an [ufoc] feature, in addition to the [uneg]. Once the latter is checked against the [ineg] of the negator (see 3.1), nikogar raises to [Spec, FocP] to check its [ $u$ foc] feature (16a). When the derivation reaches PF, TP is deleted (16b), resulting in (14a').

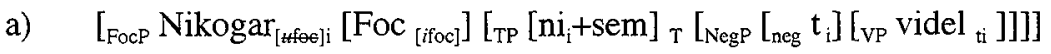

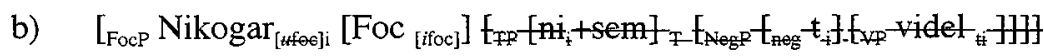

The remaining elliptical structures in (14) can be analysed along similar lines.

\section{Conclusion}

In this paper we have argued that Slovene negative pronouns are n-words constituting a special subcategory of NQs. They bear an [uneg] feature, and the negator ne, which is always present in overt syntax, bears an [ineg] feature. The [uneg] feature is checked (and thus deleted) against the [ineg]) of the negator under Agree. In the case of multiple occurrence of n-words, feature checking is effected via Multiple Agree - a syntactic operation which occurs simultaneously at the same derivational point between a single probe (ne [ineg]) and all the matching goals (n-words[uneg]). Structures without the overt negator have been shown to be elliptical. Since the negator is always present in overt syntax, the checking requirement of [uneg] feature(s) in n-words is met in the same way as in non-elliptical structures. At PF the negator is deleted through the PF deletion of $\mathrm{TP}$, yielding structures without an overtly expressed negator.

12 FP stands for a functional projection. 
The proposed analysis of Slovene n-words can be straightforwardly extended to nwords in Serbian/Croatian, Polish and Russian.

\section{References}

ACQUAVIVA, P. (1999). 'Negation and operator dependencies: Evidence from Italian.' Lingua 108: 137-174.

Brown, S. (1999). The Syntax of Negation in Russian. A Minimalist Approach. Stanford, CA: CSLI Publications.

CHomsky, N. (1995). The Minimalist Program. Cambridge, MA: The MTT press.

CHOMSKy, N. (1998). 'Minimalist Inquiries: the Framework.' MIT Occasional Papers in Linguistics 15, Cambridge, Massachusetts: The MIT press.

Chomsкy, N. (1999). 'Derivation by phase.' MIT Occasional Papers in Linguistics 18, Cambridge, MA: The MIT press.

Chomsky, N. (2001). 'Beyond Explanatory Adequacy.' MIT Occasional Papers in Linguistics 20, Cambridge, MA: The MIT press.

CInque, G. (1999). Adverbs and Functional Heads. A cross-Linguistic Perspective. Oxford: Oxford University Press.

HAEgeman, L. (1995). The syntax of negation. Cambridge Studies in Linguistics. Cambridge: Cambridge University Press.

Hiraiwa, K. (2000). 'Multiple Agree and the Defective Intervention Constraint in Japanese.' Proceedings of the HUMIT 2000, MIT Working Papers in Linguistics 40: 67-80, Cambridge, MA: The MIT press.

KIM, J. (2001) 'Syntactic focus movement and ellipsis: a minimalist approach', Glot International 5, št. 2: 67-73.

LASNIK, H. (1999). Minimalist analysis. Oxford: Blackwell.

PESETSKY, D. and E. Torrego. (2000). 'T-to-C Movement: Causes and Consequences.' $>$

Pesetsky, D. and E. Torrego. (2002). 'Tense, Case, the Nature of Syntactic Categories.' <http://web.mit.edu/linguistics/www/pesetsky/Torrego-Pessetsky.pdf

Progovac, L. (1994). Negative and Positive Polarity. Cambridge Studies in Linguistics. Cambridge: Cambridge University Press.

PrZEPIÓRKowsKi, A. and A. Kupść. (1997a). Negative Concord in Polish. Research Report 828 of IPI PAN. Institute of Computer Science, Polish Academy of Sciences.

PRZEPIORKowsKI, A. and A. Kupść. (1997b). 'Unbounded Negative Concord in Polish: A Lexicalist HPSG Approach.' in: J. Landsbergen, J. Odijk, K van Deemter, and G.V. van Zanten, eds., Computational Linguistics in the Netherlands 1996: Papers from the Seventh CLIN Meeting.Eindhoven: IPO, Center for Research on UserSystem Interaction, Technische Universitet Eindhoven, 129-143.

Rizzi, L. (1997). 'The Fine Structure of the Left Periphery.' Elements of Grammar. Handbook of Generative Syntax. L. Haegeman, ed., Dordrecht: Kluwer Academic Publlishers. 281-337.

SuÑER, M. (1995). 'Negative elements, islands effects and resumptive no.' The Linguistic Review 12: $233-273$.

van der Wouden, T. (1997). Negative contexts. Collocation, polarity and multiple negation. Routledge Studies in Germanic Linguistics. London and New York: Routledge.

ZaNuTIIN, R. (1991). Syntactic Properties of Sentential Negation. A comparative Study of Romance Languages, PhD dissertation, University of Pennsylvania.

\section{Povzetek \\ NIKALNI ZAIMKI V SLOVENŠC̆INI: MINIMALISTIČNA RAZČLEMBA}

$\mathrm{V}$ prispevku obravnavamo nikalne zaimke $\mathrm{v}$ slovenščini $\mathrm{z}$ medjezikovnega viđika. $\mathrm{Na}$ podlagi primerjave nikalnih elementov v angleščini, italijanščini, hrvaščini, srbščini, poljščini, ruščini in slovenščini ugotavljamo, da slovenski nikalni zaimki tvorijo posebno podvrsto nikalnih kvantifikatorjev, in razvijemo razčlembo zgradb z nikalnimi zaimki, ki temelji na modificirani inačici minimalistične teorije o potrjevanju obliko-skladenjskih oznak N.Chomskega. Slovenski nikalni zaimki so nikalni kvantifikatorji $\mathrm{z}$ neinterpretabilno nikalno oznako in zahtevajo skladenjskega potrjevalca stavčno nikalnico ne, ki nosi interpretabilno nikalno oznako. Potrditev se izvrši z operacijo Ujemaj med kvantifikatorjem $\mathrm{z}$ neinterpretabilno in nikalnico $\mathrm{z}$ interpretabilno oznako; neinterpretabilna oznaka je s tem izbrisana in nikalni zaimek je dostopen za nadaljnjo jezikovno izgradnjo. Za zgradbe, kjer se nikalni zaimki pojavljajo brez nikalnice, smo pokazali, da so izpustne; nikalnica je izpuščena na ravnini fonetične oblike, torej po skladenjski potrditvi nikalne oznake.

Predlagano razčlembo je moč razširiti na zgradbe $z$ nikalnimi zaimki $v$ hrvaščini, srbščini, poljščini in ruščini. 